\title{
An interesting case of intrathyroidal parathyroid adenoma
}

\author{
Dhalapathy Sadacharan, 1,2 Shriraam Mahadevan, 2,3 Krishnan Ravikumar, ${ }^{1}$ \\ Sankaran Muthukumar ${ }^{1}$
}

'Department of Endocrine Surgery, Madras Medical College, Chennai, Tamil Nadu, India

${ }^{2}$ Department of Endocrinology and Endocrine Surgery,

Endocrine and Speciality Clinic, Chennai, Tamil Nadu, India

${ }^{3}$ Department of Endocrinology, Sri Ramachandra Medical College, Chennai, Tamil Nadu, India

Correspondence to Dr Dhalapathy Sadacharan, drsdhalapathy@gmail.com

Accepted 10 April 2015
CrossMark

To cite: Sadacharan $D$, Mahadevan S, Ravikumar K, et al. BMJ Case Rep Published online: [please include Day Month Year] doi:10.1136/bcr-2015210351

\section{DESCRIPTION}

Intrathyroidal parathyroid adenomas are an uncommon cause of primary hyperparathyroidism (PHPT) and their prevalence varies from $1.4 \%$ to $6 \% .^{1{ }^{2}}$ We present a case of a 42-year-old woman with residual PHPT, operated elsewhere, with localisation of parathyroid tumour on ultrasonography and sestamibi scintigraphy on the right side of the thyroid gland (figure 1). Review of the operative records revealed a search for the parathyroid tumour on the right side, along the eutopic sites of the superior and inferior parathyroids up to the innominate vein. Frozen section and histopathology revealed only normal parathyroids and the patient remained hypercalcaemic postoperatively.

A few months later sestamibi scintigraphy was again performed with no change in the findings. Re-exploration did not reveal a tumour in the previously operated sites and hence the thyroid was carefully palpated and a nodule was felt in the right lobe of the thyroid. A hemithyroidectomy was performed and the cut section showed a parathyroid

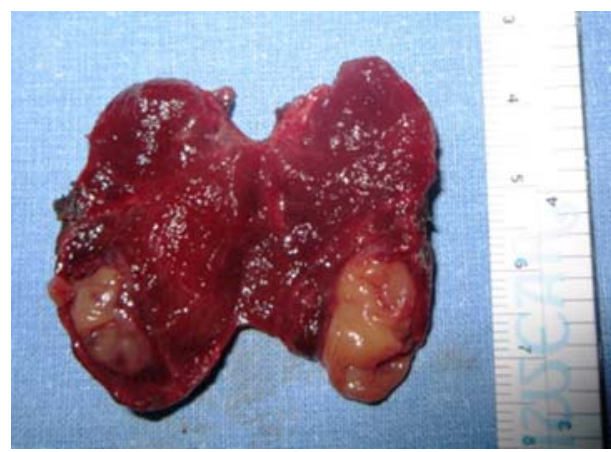

Figure 2 Cut section of right hemithyroidectomy specimen showing the classical intrathyroidal parathyroid adenoma with rim of thyroid tissue encircling the tumour.

adenoma $(1.7 \times 0.9 \mathrm{~cm})$ encircled by a rim of thyroid tissue confirming its intrathyroidal location (figure 2). Histopathology confirmed the same. Postoperatively the patient remained eucalcaemic.
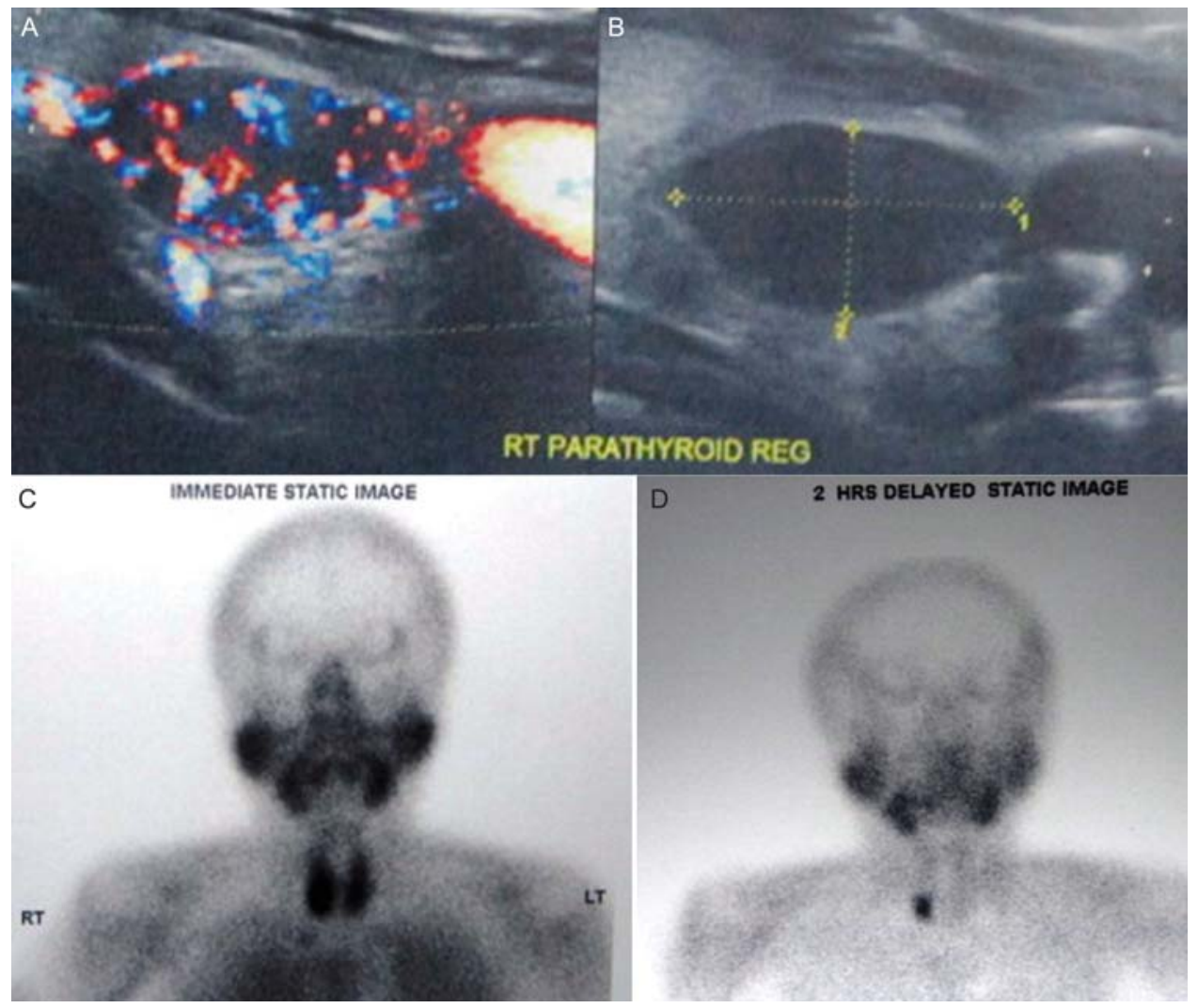

Figure 1 (A) Colour Doppler image showing parathyroid adenoma with characteristic rim of peripheral vascularity. (B) High-resolution ultrasonography showing hypoechoic lesion with a hyperechoic rim typical of a parathyroid adenoma. (C) Technetium $99 \mathrm{~m}$ sestamibi scintigraphy showing increased tracer uptake in both lobes of the thyroid in early phase. (D) Retention of the tracer in the right lobe of the thyroid in $2 \mathrm{~h}$ delayed image. 
Embryologically, the superior and inferior parathyroids develop from the fourth and third branchial pouches, respectively, and migrate caudally to their final positions. As inferior

\section{Learning points}

Intrathyroidal parathyroid adenoma is an uncommon cause of primary hyperparathyroidism.

- Intrathyroidal parathyroid adenoma is a potential cause for a failed parathyroid exploration in hyperparathyroidism.

- Minimum procedure for intrathyroidal parathyroid adenoma is hemithyroidectomy. parathyroids develop along with the thymus, their position is more variable. Migration of parathyroids into the thyroid gland is uncommon and tumour development in this location (as in our case) is encountered even less frequently. ${ }^{1}$

Competing interests None declared.

Patient consent Obtained.

Provenance and peer review Not commissioned; externally peer reviewed.

\section{REFERENCES}

1 Bahar G, Feinmesser R, Joshua BZ, et al. Hyperfunctioning intrathyroidal parathyroid gland: a potential cause of failure in parathyroidectomy. Surgery 2006;139:821-6.

2 McIntyre RC Jr, Eisenach JH, Pearlman NW, et al. Intrathyroidal parathyroid glands can be a cause of failed cervical exploration for hyperparathyroidism. Am J Surg 1997;174:750-3.

Copyright 2015 BMJ Publishing Group. All rights reserved. For permission to reuse any of this content visit http://group.bmj.com/group/rights-licensing/permissions.

BMJ Case Report Fellows may re-use this article for personal use and teaching without any further permission.

Become a Fellow of BMJ Case Reports today and you can:

- Submit as many cases as you like

- Enjoy fast sympathetic peer review and rapid publication of accepted articles

- Access all the published articles

- Re-use any of the published material for personal use and teaching without further permission

For information on Institutional Fellowships contact consortiasales@bmjgroup.com

Visit casereports.bmj.com for more articles like this and to become a Fellow 